\title{
Metal Leaching from MSW Fly Ash Before and After Chemical and Thermal Treatments
}

\author{
S. Iretskaya \\ Institute of Technology, Saint-Petersbourg, 198013, Russia
}

A. Nzihou
Ecole des Mines d'Albi-Carmaux, Centre Energétique et Environnement, Albi 81013, France

C. Zahraoui, P. Sharrock

Institut Universitaire de Technologie, Département de Chimie de Castres, Laboratoire de Chimie Inorganique, Université Paul Sabatier

Toulouse 31062, France

\begin{abstract}
Municipal Solid Waste (MSW) incineration fly ash was collected in the industrial facilities in the city of Toulouse, equipped with recent gas scrubbing equipment which collects daily $15 \mathrm{t}$ of lime treated fly ash. The fly ash contains a large proportion of water soluble chlorides, besides trace elements such asiron, zinc, titanium and copper. Presently, the fly ash is landfilled after a cement solidification process. Matrix stability and leaching behavior of heavy metals $(\mathrm{Cd}, \mathrm{Cu})$ from samples of doped MSW fly ash were examined before and after chemical and thermal treatments. A new phosphate process leading to hydroxylapatite formation is described. To evaluate it's performance as a stabilization process, cupric and cadmium ions were added as typical pollutant tracers and their distribution was studied as a function of different treatment parameters. The hydroxylapatite process used effectively removes chloride ions in the water extract and retains most of the added metal ions in the solid residues. Evaluation of this procedure as a cold process shows 50\% reduction in leachable metal ions. Calcination of the solid residues at $900^{\circ} \mathrm{C}$ resultsin agglomerated partices with increased resistance to metal ion dissolution. This is attributed to heavy metal incorporation in the hydroxylapatite matrix formed during the thermal treatment. Thus, combined chemical and thermal treatments are efficient for heavy metal sabilization in MSW fly ash.
\end{abstract}

\section{INTRODUCTION}

Management of municipal solid waste (MSW) requires the consideration and understanding of many diverse environmental and ecological impacts that result from the ultimate disposal of these wastes. Landfilling is the most expedient, inexpensive disposal method for MSW; however, groundwater pollution from landfill leachate is of concern, as are gas emissions. Furthermore, any toxic products present in the original waste will remain in unknown, uncontrolled form in the landfill. Legislation in France calls for the ban of standard landfilling sites in the year 2002. Only non-recyclable waste, socalled "ultimate waste", will be admitted in authorized, wellequipped sites. To meet these requirements, recyclable MSW will have to be removed in an efficient and cost-effective manner. One method of organic waste separation is combustion. This process recycles or converts waste to steam or energy. The non-combustible residues from this process are classified as bottom ash (which contains the ferrous, magnetically removed metals) and fly ash. Comparative studies of bottom and fly ash have shown that fly ash is enriched in more volatile metals such as mercury, lead and cadmium $[1,2]$. The bottom ashes are generally considered to be suitable for use as an additive in concrete, or for use as roadbase material. Contamination of fly ash with toxic heavy metals is controlled by the volatility of these metals and their chlorides at high temperature and their effective precipitation and retention in gas scrubbing equipment. Demanding atmospheric emission standards have led to efficient neutralization techniques for hydrochloric acid and heavy metals contents. The procedure usually involves lime injection, with sodium carbonate as an alternative [3].

As an alternative method to the actually used cement solidification process prior to landfilling, we have developed a new process consisting in a phosphate chemical treatment followed by a thermal treatment. The phosphate treatment is an aqueous sol-gel process which produces agglomerated fly ash particles and extracted chlorides. The thermal treatment consists, after drying at $60^{\circ} \mathrm{C}$, in calcining the fly ash 


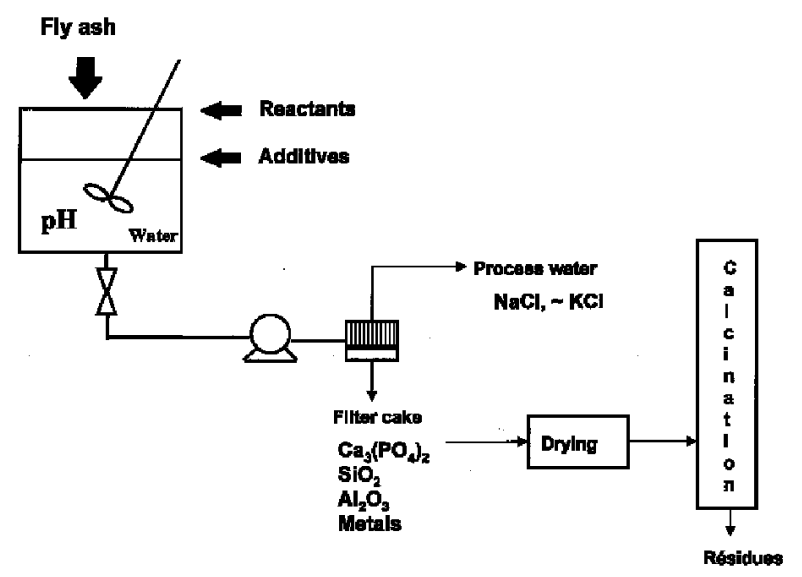

FGURE 1. Chemical treatment diagram showing wet process followed by filtration and further heat treatment.

agglomerates in air at $900^{\circ} \mathrm{C}$.

We have added small amounts of heavy metals $(\mathrm{Cu}, \mathrm{Cd})$ to generate doped fly ash in order to study matrix stability and leaching behavior of treated samples. Our main objective was to determine whether or not the chemical treatment, alone or combined with a thermal treatment, stabilizes the residues by decreasing the amounts of metal ions released in leaching tests carried out with water and complex forming solutions.

\section{MAT田ALSAND METHODS}

1- Sample collection. The fly ash used in this study was collected as a homogeneous $10 \mathrm{~kg}$ sample from the municipal waste incinerator in Toulouse. This facility burns 450 tons of waste daily and produces 15 tons of fly ash. The stack scrubber was installed in 1994 and includes a lime injection unit followed by filters which collect the fly ash. Gases are then sent through a gas washing unit which collects residual hydrochloric acid and heavy metals. The process water is treated, and filter cake residues are produced. These cakes were not included in the present study.

2- Sample compostion. The collected fly ash contains calcium, silica, alumina and chloride ions as major constituents characterized by energy dispersive X-ray analysis (EDX).Major elements include, by weight : $\mathrm{Ca}(8.2 \%), \mathrm{Na}(3.1 \%)$, and $\mathrm{Cl}$ $(9.0 \%)$; the trace elements include $\mathrm{Cu}(0.08 \%)$ and $\mathrm{Cd}(0.02 \%)$.

3 - Process description and experimental procedure. In a first series of experiments, $1 \mathrm{~kg}$ of fly ash and 21 of distilled water were introduced in a stirred tank reactor of $10 \mathrm{l}$ capacity. $10 \mathrm{~g}$ of copper or cadmium was added in the form of a concentrated solution. To homogenize the mixture, the suspension was stirred 30 minutes at room temperature $\left(20^{\circ} \mathrm{C}\right)$. The suspension was filtered and the cakes were air-dried in a Jouan oven at $60^{\circ} \mathrm{C}$. The process waters were sampled for chemical analysis. The solid residues were sampled as $100 \mathrm{~g}$ aliquots and calcined in sintered alumina crucibles under air atmosphere at $900^{\circ} \mathrm{C}$ in a Thermolyne muffle furnace. In a second series of experiments, to a mixture containing1 $\mathrm{kg}$ of fly ash and 21 of distilled water and $10 \mathrm{~g}$ of copper (or cadmium) was added $20 \mathrm{~g}$ of $\mathrm{Ca}(\mathrm{OH})_{2}$ and $60 \mathrm{~g}$ of $\mathrm{H}_{3} \mathrm{PO}_{4}$. The suspension was stirred 30 minutes and treated as described above. The various steps of the process are illustrated in Figure 1.

4- Quantitativechemical analysis. $2.0 \mathrm{~g}$ samples were digested 15 minutes with $30 \mathrm{ml}$ concentrated nitric acid under reflux. The suspensions were cooled and filtered. The filtrates were diluted to $100 \mathrm{ml}$ and examined for various elements. The chloride contents were analyzed by a silver nitrate titration method using potentiometric end point determination.

5- Leaching tests. Experiments were carried out using water or $1 \%$ EDTA or tartaric acid solutions with a liquid to solid ratio of $200 \mathrm{ml}$ of solution for $100 \mathrm{~g}$ of solids. The suspensions were stirred for half an hour and filtered on Buchner funnels to separate the solid and liquid phases. Leach liquors were analyzed for $\mathrm{Cu}, \mathrm{Cd}, \mathrm{Ca}, \mathrm{Na}$ and $\mathrm{Cl}$. The solids were analyzed for the same elements following nitric acid digestion.

6- Analytical techniques Atomic absorption measurements were made with a Unicam model 919 spectrophotometer using airacetylene and multielement discharge lamps for calcium, copper and cadmium. A Corning model 410 emission spectrophotometer was used with air-natural gas to determine sodium concentrations. A Jeol scanning electron microscope was used to observe the samples, which were analyzed with no sputtered coating by spreading small samples of powder on conductive tape. Identification and semi quantitative analysis were performed with a Link analytical EDX analyzer. A Sieffert XRD diffractometer was used to obtain powder X-ray diffraction patterns for the phosphate treated fly ash and a commercial hydroxylapatite reference sample.

\section{RESULTSAND DISCUSSON}

The analytical results concerning the fly ash used in our experiments show that copper and cadmium are present in negligible amounts. $1 \%$ of copper was added as a typical transition metal and $1 \%$ of cadmium as a representative heavy metal [4]. The presence of these metals in easily quantified concentrations helps to study their leaching behavior.

Distribution of copper and cadmium: Table 1a presents the results obtained when fly ash spiked with $1 \%$ copper is treated with water. $100 \%$ of the copper remains in the solid phase. On the other hand, the majority of soluble chloride salts are extracted by water, as has been previously reported [5] The insolubility of copper may simply be explained by the

TABLE 1a. Behavior of Ry Ash Spiked with Copper

\begin{tabular}{lllll}
\hline Element (weight \%) in: & $\mathrm{Cu}$ & $\mathrm{Ca}$ & $\mathrm{Na}$ & $\mathrm{Cl}$ \\
& & & & \\
Water extract & 0 & 8 & 52 & 53 \\
Solid residue & 100 & 92 & 48 & 47
\end{tabular}

Solid residue leaching test

Element $(\%$ extracted $) \quad \mathrm{Cu} \quad \mathrm{Ca} \quad \mathrm{Na} \quad \mathrm{Cl}$

$\begin{array}{lllll}\text { With water } & 0 & 13 & 32 & 47\end{array}$

With $\operatorname{EDTA}($ at $\mathrm{pH}=6) \quad 41 \quad 20 \quad-$

With tartaric acid (at $\mathrm{pH}=6) \quad 66 \quad 5 \quad$ - 
TABLE 1b. Behavior of Hy Ash Spiked with Cadmium

\begin{tabular}{lllll}
\hline Element (weight \%) in: & $\mathrm{Cd}$ & $\mathrm{Ca}$ & $\mathrm{Na}$ & $\mathrm{Cl}$ \\
& & & & \\
Water extract & 0.4 & 8 & 19 & 74 \\
Solid residue & 99.6 & 92 & 81 & 26
\end{tabular}

Solid residue leaching test

$\begin{array}{lllll}\text { Element }(\% \text { extracted }) & \mathrm{Cd} & \mathrm{Ca} & \mathrm{Na} & \mathrm{Cl} \\ \text { With water } & 0 & 12 & 58 & 21 \\ \text { With EDTA }(\text { at } \mathrm{pH}=6) & 53 & 12 & - & - \\ \text { With tartaric acid }(\text { at } \mathrm{pH}=6) & 9 & 4 & - & -\end{array}$

formation of cupric hydroxide at the $\mathrm{pH}$ resulting from water treatment $(\mathrm{pH}=11.5)$. Further water extraction of the solid residues at neutral $\mathrm{pH}$ was unable to dissolve cupric hydroxide. EDTA or tartaric acid, both adjusted to $\mathrm{pH}=6$ to accelerate the leaching process, removed partly cupric ions from the solid phase (from 41 to $66 \%$ of the copper contents). Similar results were observed at $\mathrm{pH}=8$, showing that dissolution is related to metal-ligand complex formation, as could occur with organic material in the environment.

Table $1 \mathrm{~b}$ presents the distribution of cadmium ions in solid and liquid phases following analogous treatments. In this case, very little cadmium is soluble at high $\mathrm{pH}$, which may be accounted for by the formation of sparingly soluble hydroxycadmiates and insoluble cadmium hydroxide. These results show that the distribution of metals depends on the nature of the considered elements, its capacity to interact with organic ligands or hydroxide ions to form stable, soluble or insoluble complexes.
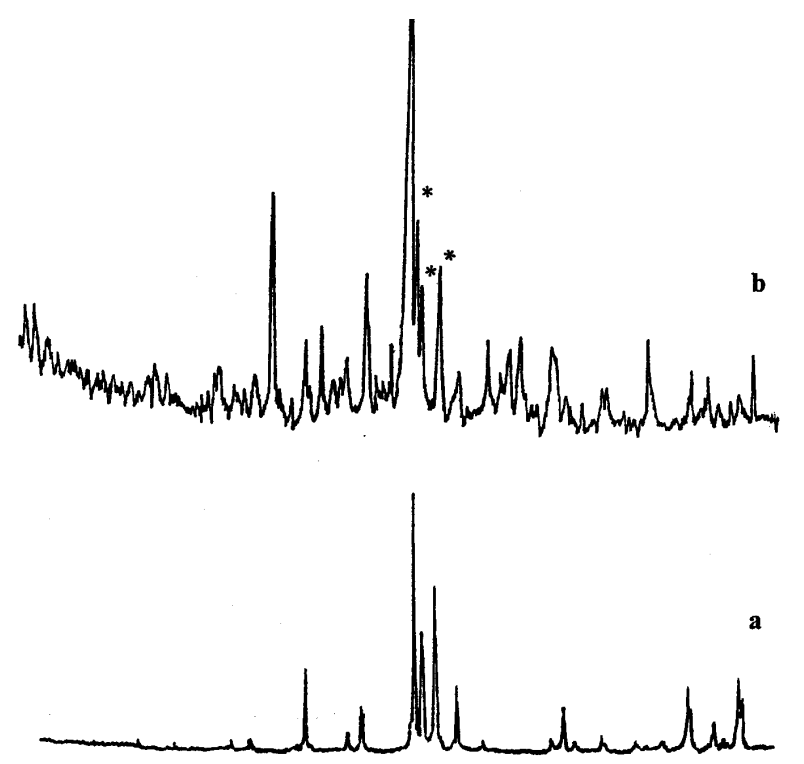

FGURE2. X-ray diffraction patterns of treated fly ash (b) showing matching peaks $(*)$ and (a) reference hydroxylapatite.
Calcium phosphate treatment: When calcium and orthophosphate ions are mixed in solution at neutral $\mathrm{pH}$, a gel forms which may precipitate hydroxylapatite when the proper calcium to phosphorous ratio is present. Reaction 1 occurs to completion because of the very low solubility product of hydroxylapatite [6].

$$
\begin{gathered}
10 \mathrm{Ca}_{(a q)}^{2+}+6 \mathrm{H}_{3} \mathrm{PO}_{4(a q)}+2 \mathrm{OH}_{(a q)}^{-} \\
\rightarrow \mathrm{Ca}_{10}\left(\mathrm{PO}_{4}\right)_{6}(\mathrm{OH})_{2(s)}
\end{gathered}
$$

By isomorphic substitution, metal ions may be incorporated in the solid matrix according to reaction 2 .

$$
\begin{aligned}
& \mathrm{Ca}_{10}\left(\mathrm{PO}_{4}\right)_{6}(\mathrm{OH})_{2(s)}+x C d_{(a q)}^{2+} \\
\rightarrow & C a_{(1-x)} C d_{x}\left(\mathrm{PO}_{4}\right)_{6}(\mathrm{OH})_{2(s)}+x C a_{(a q)}^{2+}
\end{aligned}
$$

Figure 2 compares the powder diffraction pattern of a reference hydroxylapatite to that obtained for the fly ash treated by the previously described phosphate process. Hydroxylapatite is identified in the treated fly ash residues by the presence of the characteristic diffraction peaks for interplanar distances of $\mathrm{d}=2.81 ; 2.78$ and $2.71 \AA$ And labeled $*$ in figure 2 .

When a calcium phosphate gel was formed, no major change was observed with respect to water solubility as shown in Table 2a. On the other hand, a significant decrease in cupric or calcium ion extraction by complexing ligands was observed, reaching over $50 \%$. Interestingly, some cadmium is released near neutral $\mathrm{pH}$ following calcium phosphate treatment, as shown by the results presented in Table $2 \mathrm{~b}$. This may be related to the high concentration of chloride ions observed under our experimental conditions, leading to the dissolution of cadmium hydroxide in the form of water soluble chlorocadmiates. Once again, the main effect of calcium phosphate treatment is to reduce the calcium and heavy metal dissolution in leaching tests.

Heat treatment and SEM-EDX evaluation. SEM-EDX examination of fly ash shows a heterogeneous mixture of

TABLE 2a. Behavior of Calcium Phosphate Treated with Copper

Treated fly ash

Element (weight \%)

Process water

Treated solid residue

$\begin{array}{llll}\mathrm{Cu} & \mathrm{Ca} & \mathrm{Na} & \mathrm{Cl} \\ 0 & 6 & 63 & 45 \\ 100 & 94 & 37 & 55\end{array}$

Treated solid residue leaching test

$\begin{array}{lllll}\text { Element }(\% \text { extracted) } & \mathrm{Cu} & \mathrm{Ca} & \mathrm{Na} & \mathrm{Cl} \\ \text { With water } & 0 & 15 & 33 & 47 \\ \text { With EDTA }(\text { at } \mathrm{pH}=6) & 20 & 11 & - & - \\ \text { With tartaric acid (at } \mathrm{pH}=6) & 14 & 0.1 & - & -\end{array}$



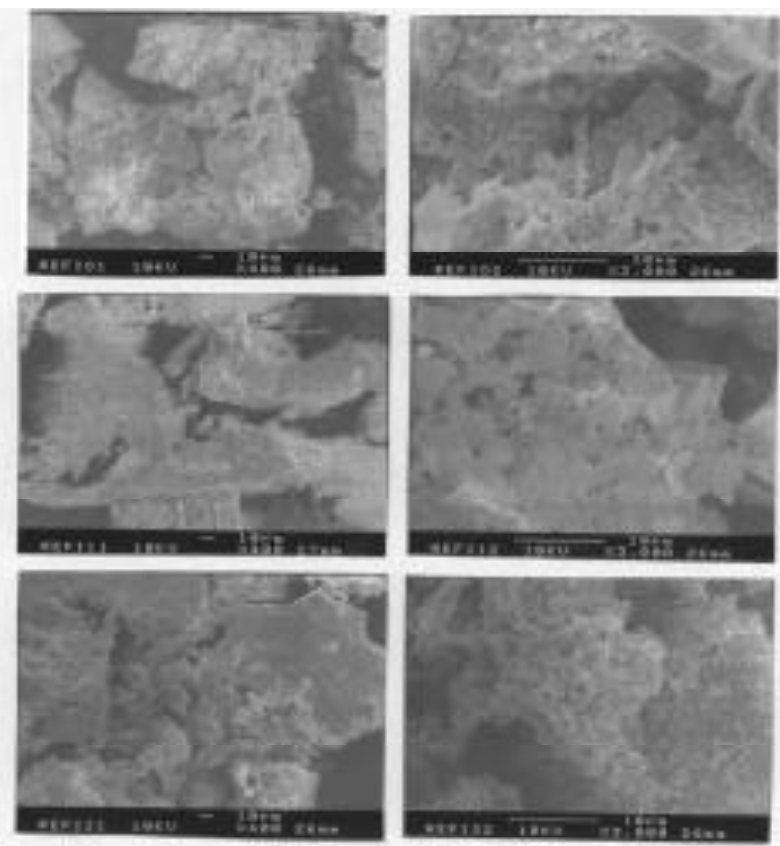

FGURE 3. SEM pictures of fly ash (top), treated fly ash (middle) and treated and calcined fly ash (bottom).

elements and shapeless particles (Figure 3). Washing fly ash with water to remove soluble salts caused an increase in surface microporosity of the remaining particles. Some of the larger particles are observed to have finer particles stuck on their surfaces. Fly ash treated with calcium phosphate gel shows agglomerated particles with over 100 micrometers diameter and surfaces covered with 1micrometer nodules. The calcium phosphate treated fly ash examined after air calcination at $900^{\circ} \mathrm{C}$ showed a reduced size for the surface nodules, with retention of a porous, non-dense structure. This can be explained by the crystallization and partial sintering of the solids.

Table 3 presents the effect of calcination on heavy metal dissolution by aqueous ligands. A further significant decrease in copper and cadmium leachability is observed. This effect may be related to the incorporation of metal ions in a more compact, crystalline and insoluble calcium phosphate matrix. Substitution of calcium by other metals accounts for the

TABLE 3. Effect of Calcination on \% Metal Extracted in Leaching Tests

\begin{tabular}{lcccc}
\hline Fly ash spiked with: & $\mathrm{Cu}$ & $\mathrm{Cu}$ & $\mathrm{Cd}$ & $\mathrm{Cd}$ \\
Leaching test with: & EDTA & $\begin{array}{l}\text { tartaric } \\
\text { acid }\end{array}$ & $\begin{array}{c}\text { EDTA } \\
\text { tartaric } \\
\text { acid }\end{array}$ \\
Fly ash solid residue at $20^{\circ} \mathrm{C}$ & 41 & 66 & 53 & 9 \\
Fly ash calcined at $900^{\circ} \mathrm{C}$ & 2.0 & 0 & 2.0 & 0 \\
Treated fly ash at $20^{\circ} \mathrm{C}$ & 20 & 14 & 35 & 0.2 \\
Treated fly ash calcined at $900^{\circ} \mathrm{C}$ & 0.1 & 0 & 19 & 0.01 \\
\hline
\end{tabular}

TABLE 2b. Behavior of Calcium Phosphate Treated Fy Ash with Cadmium

Treated fly ash

$\begin{array}{lcccc}\text { Element (weight \%) } & \mathrm{Cd} & \mathrm{Ca} & \mathrm{Na} & \mathrm{Cl} \\ \text { Process water } & 13 & 11 & 18 & 69 \\ \text { Treated solid residue } & 87 & 89 & 82 & 31\end{array}$

Treated solid residue leaching test

$\begin{array}{lllll}\text { Element }(\% \text { extracted }) & \mathrm{Cd} & \mathrm{Ca} & \mathrm{Na} & \mathrm{Cl} \\ \text { With water } & 0.2 & 11 & 75 & 23 \\ \text { With EDTA }(\text { at } \mathrm{pH}=6) & 35 & 9 & - & - \\ \text { With tartaric acid }(\text { at } \mathrm{pH}=6) & 0.2 & 1 & - & -\end{array}$

decreased solubility of heavy metals in the hydroxylapatite structures [7,8]. The cadmium spiked untreated fly ash has a low concentration of leacheable cadmium (2\%), possibly due to the loss of cadmium as volatile chloride during the calcination step. The treated fly ash shows higher retention of cadmium in the phosphate matrix during calcination. This leads to some cadmium release during the EDTA leaching test (19\%).

\section{CONCLUSION}

Chemical treatment of MSW fly ash by a calcium phosphate gel addition effectively reduces heavy metal ion solubility, particularly under aggressive chelating conditions. This conforms to present knowledge on heavy metal removal from contaminated soils [9]. Thermal treatment also significantly affects the solubility of metal ions with respect to chelating ligands. The observed decreases in metal ion leachate concentrations may be attributed to the incorporation of the metals in a calcium phosphate matrix. The thermal treatments under mild conditions $\left(900^{\circ} \mathrm{C}\right)$ generally avoid excessive metal loss by evaporation [10], but contribute to apatite crystallization, as confirmed by SEM and X-ray diffraction analysis.

The chemical treatment method proposed presents the advantage of eliminating some soluble chlorides combined with the advantage of leading to a low temperature thermal treatment for the solidification-stabilization step. In order to optimize the best combination of chemical and thermal treatments, several parameters need to be explored and include: heavy metal concentration, particle size control, drying technique, and temperature and duration of calcination, nature and quantities of phosphate additives. In parallel with this experimental approach, thermodynamic equilibrium and mass transfer of metal ions in mineral matrixes are being examined to evaluate the distribution of pollutants. These combined efforts should yield new processes $[11,12]$ for municipal solid waste incinerator fly ash disposal or recycling.

\section{ACKNOWLGMENT}

We thank Dr. J.V. Lake of the European Environmental Research Organization for providing a research fellowship to 
S.Irestskaya and Dr. Kersaudy of the Société d'Exploitation Thermique du Mirail for technical collaboration..

\section{UTERATURECITED}

1. Kirby, C.S.; Rimstidt J.D., "Mineralogy and Surface Properties of Municipal Solid Waste Ash,” Env. Sci. Technol., 27, 652-660 (1993).

2. Eighmy, T., Eusden, J., Krzanowski, J., Domingo, D., Stamfli, D., Martin, J., Erickson, P., "Comprehen sive Approach Toward Understanding Element Speciation and Leaching Behaviour in Municipal Solid Waste Electrostatic Precipitator Ash,” Environ. Sci. Technol., 29, 629-646 (1995).

3. Uchida, T.; Itoh, I.; Hadara, K., Immobilization of Heavy Metals Contained in Incinerator Fly Ash by Application of Soluble Phosphate Treatment and Disposal Cost Reduction by Combined Use of "High Specific Surface area Lime". Wase Management., 16, 475-481 (1996).

4. Iretskaya, S., Nzihou, A., Zahraoui, C., Sharrock, P., "Characterization and Chemical Treatment Municipal Solid Waste Incinerator Fly Ash", Environmental Technology, submitted.

5. Kirby, C.S.; Rimstidt J.D. "Interaction of Municipal Solid Waste Ash With Water,". Env. Sci. Technol., 28, 443451 (1994)
6. Kanedo, H., "Evaluation of Municipal Solid Waste Incinerator Fly Ash Toxicity and the Role of Cadmium by two Aquatic Toxicity Tests," Waste Management, 16, 555-559 (1996)

7. Chen, X., Wright, J.V., Conca, J.L., Peurrung, L.M.," Effects of pH on Heavy Metals Sorption on Mineral Apatite," Env. Sci. Technol., 31, 624-631 (1997)

8. Carpena, J.; Lacout, J.L, "Des Apatites Naturelles aux Apatites SynthÈtiques. Utilisation des Apatites comme Matrice de Conditionnement des Déchets Nucléaires Séparés," Lact. Chim., 2, 3-9 (1997)

9. Niele, C.N., Bricka, R., Chao, A., " Evaluating Acids and Chelating Agents for Removing Heavy Metals from Contaminated Soils," Environmental Progress, 16, 274-280 (1997).

10. Jacob, A., Stucki, S., Kuhn, P., " Evaporation of Heavy Metals during the Heat Treatment of Municipal Solid Waste Incinerator Fly Ash," Env. Sci. Technol, 29, 2429-2436 (1995)

11. Mizutani, S.; Yoshida, T.; Sakai, S.; Takatsuki, H., "Release of metals from MSW I Fly Ash and Availability in Alkali Condition," Waste Management., 16, 537-544 (1996).

12. Kida, A.; Noma, Y.; Imada, T., "Chemical Speciation and Leaching Properties of Elements in Municipal Incinerator Ashes," Wase Management., 16, 527-536 (1996). 